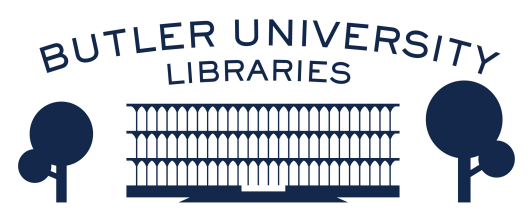

Journal of Hindu-Christian Studies

Volume 3

Article 8

January 1990

\title{
Book Review: "River of Compassion: A Christian Commentary on the Bhagavad Gita"
}

David C. Scott

Follow this and additional works at: https://digitalcommons.butler.edu/jhcs

Part of the Religion Commons

\section{Recommended Citation}

Scott, David C. (1990) "Book Review: "River of Compassion: A Christian Commentary on the Bhagavad Gita"," Journal of Hindu-Christian Studies: Vol. 3, Article 8.

Available at: https://doi.org/10.7825/2164-6279.1031

The Journal of Hindu-Christian Studies is a publication of the Society for Hindu-Christian Studies. The digital version is made available by Digital Commons @ Butler University. For questions about the Journal or the Society, please contact cbauman@butler.edu. For more information about Digital Commons @ Butler University, please contact digitalscholarship@butler.edu. 
complexities that need to be taken into account in looking into that most intricate of all subjects - the meeting of person with person, tradition with tradition, faith with faith" (p. 113).

John B. Carman

Center for the Study of World Religions

Harvard Divinity School

Cambridge, Massachusetts

In Search of Self in India and Japan: Toward a Cross-Cultural Psychology. Dr. Alan Roland. Princeton, New Jersey: Princeton University Press, 1988, xxxii + 386p.

Roland, a psychoanalyst, compares the extended familial-self typical of Indian and Japanese experience with the individualized self-concept of America. This difference is significant for one's conception of marriage, social relations, art, time and space, subject-object relations and the spiritual goal. Freudian categories (egoideal, superego, etc.) are adopted but contextualized through clinical work with Indian and Japanese patients. Roland demonstrates convincingly that self-concept varies radically according to culture. Therefore, application of Freudian or other Western categories directly to Eastern experience is invalid. Psychological structuring is shown to be embedded in the distinct views of human nature, social patterns and childrearing practices of the various cultures.

This book adds crucial psychological dimensions to our study of Eastern philosophy and religion. It catches the vital nuances of self-experience that escape philosophical and historical approaches. It works well in senior undergraduate and graduate classes and is essential for libraries. The treatment of Japan, however, is weak. The analysis of Indian experience is overly influenced by Vedanta philosophy and shows no sensitivity to the cultural diversity within India. Yet, in spite of these limitations, the book opens important new ground.

Harold Coward

University of Calgary

Calgary, Canada

River of Compassion: A Christian Commentary on the Bhagavad Gitā. Bede Griffiths. Warwick, N.Y.: Amity House, 1987, 328p., \$11.95.

Another commentary on the Gitä? There can be little doubt but that in India-both in ancient and in modern times-and in the West-throughout the present century - there has been a literal plethora of bhasyas on this spiritual classic. Arguably the Git $\bar{a}$ is one of, if not the most popular of the religious texts to come from the Hindu tradition. However, as Father Bede rightly points out in his 


\section{Book Reviews}

Introduction, it does not belong to Hindus alone, but to the entire world. And it belongs to all women and men not in the manner that another literary composition does, but rather as a part of the specifically spiritual inheritance of the human race. There is, of course, the edition of the Gita by Professor Franklin Edgerton. Surely, one might legitimately think, these two volumes [subsequently appearing without the Sanskrit as a single volume], containing the original Sanskrit with a literal translation on the opposite page, notes, an 'interpretation', and for good measure, a reprint of Sir Edwin Arnold's well-known poetical rendering, are all that is needed for the serious student and the general reader. In French there is the excellent, scholarly, and lucidly objective study by Etienne Lamotte, Notes sur la Git $\bar{a}$, which anticipates much that R. C. Zaehner has to say, based on his somewhat 'unvarnished' translation of his own rearranged version entitled The Bhagavad-Gita . For those who prefer a commentator whose spiritual roots are in the same religious tradition from which the Git $\bar{a}$ has come, there are the well-known translations/commentaries of such illustrious Indian savants as Sankara and Ramanuja, or in our own time those of Sarvepalli Radhakrishnan, Mahatma Gandhi and Sri Aurobindo. Each of these, of course, has his own interests, with Edgerton, Lamotte and Zaehner attempting to explicate the actual content of the Gita . In this they seem to have been reacting both against the Indian tradition [ancient and modern] in which the commentator seeks to serve the purposes of his own views, and against the German tendency, initiated by Richard Garbe and continued notably by Rudolf Otto, which sought to establish an Ur-Git $\bar{a}$, from which they eliminated whatever was considered to be alien to the matter in hand as they [each in his own individual way] understood it. While Father Bede is, of course, well aware of these various 'traditions' in the history of Gita commentary, his own work is refreshingly innocent of all of this. What he intends, and in which he is remarkably successful, is "a practical spiritual guide to a Christian or to anyone who is in search of a guide on the spiritual path." He clearly renounces any intention of suggesting that there was even the slightest Christian influence in the composition of the Gita $\bar{a}$, or that there is anything specifically Christian about it at all. A 'practical spiritual guide' is what Father Bede intends and this he provides for the benefit of those who do not want an academic study of the Gita, of which, as we have seen, there are plenty. The River of Compassion is for those who want to explore the bearing the Git $\bar{a}$ could have on their own lives.

Father Bede's reflections are in the context of and legitimized by the realization that just as 'no man is an island' so no faith tradition can stand alone. We all share a common humanity and, in our 'global village' we all need to share the insights of the different religious traditions of the world. Indeed, Father Bede successfully demonstrates how the message of the Gita can throw new light on many aspects of the Christian Gospel, and in turn how the Gita "gathers a new meaning when seen in the perspective of the Gospel."

The chapters of the commentary, which were originally given as talks to the members of Father Bede's ashram, Shantivanam, follow the eighteen chapters of the Git $t \bar{a}$. Our commentator insightfully takes his cue from the fact that each chapter of the religious text concerns a particular yoga, a particular reality/experience which serves as a means of transformation in the lives of women and men. Thus, for 
example, the second chapter focuses on 'the yoga of discriminative wisdom', or viveka - that peculiar discernment of eternal reality within the whole complex of nature and life. In a world in which there is so little authenticity, in which nothing is what it appears to be, in which the real and the unreal are hopelessly and ubiquitously intermixed, 'discriminative wisdom' is both the means and the end [the complementarity of means and end is a unique and fascinatingly profound insight of the Hindu religious tradition], the journey to and the point where we discern eternal reality distinct from and yet immanent in the changing reality of everyday experience. Father Bede rightly points out that this does not mean that we are trying to opt out of time and space; rather we are trying to see time, space and matter in the light of eternity, of the Atman, the Spirit which pervades the whole of creation. The Atman, the Supreme Spirit is evocatively likened to the sun, in which light is fully present, fully realized. Indeed, it is the light of the sun which is reflected in all "names" and "forms" and while we never actually see the light, qua light, the reality of anything can only be seen in the light. That, we are told is the basic pattern of perception which should be ours. God is light, and God manifests Godself in creation and in all humanity. The degree of manifestation depends on the receptivity of the different elements. "The aim is that each person should be a pure reflection of the light. That is the background of the whole of the Gita

In this fashion the reader is led authoritatively but gently through the entire text of the Gita -through the yogas of 'action' and 'partial knowledge', of 'meditation' and 'imperishable eternal', of the 'vision of the cosmic form' and 'devotion', to mention only some along the way. The climax of the Gità 's teaching comes with the 'yoga of liberation by renunciation'. This is the way of bhakti, of the love of God. This is the yoga in which "the whole mind is fixed on God all the time and one surrenders everything to Him and does everything as an offering to Him. It is a total self-surrender." But it is more, for in the offering of the self one opens oneself to the divine and experiences not only that we love God, but that God loves us. Following Zaehner, Father Bede suggests that the fact/experience of God's love for women and men is the culmination the Hindu religious tradition, just as it is the consummation of the Christian faith. Indeed, here is the climax of both the Hindu and Christian revelations: it is not merely that we love God, but that God loves us.

Throughout Father Bede brings into his discussion a number of evocative elements, with specific references, from a variety of sources-from Jesus and the Buddha, from St. Paul and Sankara, from Andal and the Virgin Mary, from Sri Ramakrishna and St. Augustine, from Guru Amardas and the Greek Fathers, suggesting striking inter-faith linkages which are of immense value in reflecting on the meaning of the message of the Gita . Unfortunately, however, these are not always entirely accurate and can cause considerable distraction to the knowledgeable reader who will recognize a number of 'slips.' For example, the famous prayer "From the unreal, lead me to the real. From darkness, lead me to the light. From death, lead me to immortality." is not to be found in "the invocation from the Isha Upanishad" - at least not in any of the texts available to the reviewer-as Father Bede indicates [p. 15], but in the Brhadaranyaka Upanisad [1.3.28]. Again, the New Testament reference on p. 322 should be to I John 4:10. However, in and through it 


\section{Book Reviews}

all, as anyone who knows Father Bede would certainly anticipate, the direction of his journey is not so much that of the academic as it is of the guru, the spiritual guide. Told in another, though not unrelated, context, an amusing story nicely captures the design and the flavor of Father Bede's exposition. It seems that a learned scholar was giving a lecture on the Git $\bar{a}$ in Sanskrit to an audience whose members were so bored that one by one they all departed, leaving a solitary old man sitting totally enraptured. The lecturer was consoled by the fact that at least one person was appreciative of his erudition, and expressed his gratitude at the end of the discourse. "Oh," said the old man, "I wasn't listening to your talk at all. I saw Krishna in front of you and I was worshipping the Lord." The Git $\bar{a}$ is to be read in such a way as to enable the reader to experience the indwelling presence of God, and to awaken love for the Lord. To the extent that is possible for this to happen in and through a book, Father Bede has been successful in good measure and God-seekers in all faith traditions cannot but be grateful to him for helping this to happen in the River of Compassion.

David C. Scott

United Theological College

Bangalore, India

Spirituality in Interfaith Dialogue. Edited by Tosh Arai and Wesley Ariarajah. Maryknoll: Orbis Books, 1990. (Also Geneva, WCC, 1989) xi + 103 p.

This is a collection of personal stories shared by Christians from various continents at a WCC seminar on the same theme, held in Kyoto, Japan, in December, 1987. The collection is preceded by a report on and the statement of the seminar.

The narratives make interesting reading. Each one tells us simply how he/she has come into contact with another faith and what this dialogue has done to him/her. Stories cannot be summarized. But one can note some common trends or special points. For everyone it has been a learning experience. All have been enriched by it, while rediscovering their own identity as Christians. At this level of spirituality one does not see the kind of argument that one might hear at an intellectual level of discussion. But one feels one's horizons broadened; one learns new ways of looking at and experiencing God and the world. In every case it has been an experience of growth, through inclusion and integration.

Predictably, most of the encounters have been with Hinduism and Buddhism and at the level of prayer and sadhana. Only one speaks about Islam and one about aboriginal religion. Some speak about the need for a common commitment to work for justice. But except for one example from Sri Lanka, where a workers' fellowship bringing together Hindus, Buddhists, Christians and Marxists ventures even into common worship inspiring them to a common struggle, the others are not convincing. 